\title{
Aktivitas Antidiabetes Ekstrak Air-Etanol, $n$-Heksan, dan Etil Asetat Uwi Banggai (Dioscorea alata L.) Dengan Metode Induksi Aloksan Pada Mencit Jantan (Mus musculus)
}

\section{(Antidiabetic Activity of Water-Ethanol, n-Hexane, and Ethyl Acetate Extracts of Dioscorea alata L. Using Alloxan Induction Method In White Rats (Mus musculus)}

\author{
Khildah Khaerati*, Delina Amini, Ihwan \\ *Laboratorium Farmakologi-Biofarmasi, Jurusan Farmasi, Fakultas Matematika dan Ilmu Pengetahuan Alam, Universitas \\ Tadulako, Palu, Indonesia. \\ E-mail:idhapharm@gmail.com
}

Article Info:

Received: 6 Juni 2020

in revised form: 16 Agustus 2020

Accepted: 29 Agustus 2020

Available Online: 30 September 2020

Keywords:

Alloxan

Diabetes Melitus

Mus musculus

Extract

Dioscorea alata $\mathrm{L}$.

Corresponding Author:

Khildah Khaerati

Laboratorium Farmakologi-

Biofarmasi

Jurusan Farmasi

Fakultas Matematika dan Ilmu

Pengetahuan Alam

Universitas Tadulako

Palu

Indonesia

Email : idhapharm@gmail.com

\begin{abstract}
Hyperglycemia is a condition of increased blood glucose levels caused by insufficient insulin enzymes produced to control blood sugar levels in the body. This study aimed to determine the activity of ethanol-water, nhexane, and ethyl acetate extracts of Dioscorea alata L. in reducing blood glucose levels in hyperglycemia modeled mice that were given intraperitoneal alloxan induction. 25 white rats were divided into 5 groups of test animals. Each group consists of 5 mice. The first group was given $0.5 \%$ sodium carboxymethylcellulose solution as a placebo, the second group was given $0.65 \mathrm{mg} / \mathrm{kg} \mathrm{BW}$ glibenclamide as a positive comparison group, the third group was given the suspension of ethanol-water extract, the fourth group was given $n$-hexane extract, and the fifth group was given ethyl acetate extract at a dose of $140 \mathrm{mg} / \mathrm{kg} \mathrm{BW}$. The test preparation was orally given within 14 days of testing. The test was measured as the initial blood glucose levels of mice after alloxan induction and after giving the test preparation suspension. The results of the qualitative analysis illustrate that the water-ethanol extract can reduce blood glucose levels by $31.39 \%$, n-hexane extract by $51.11 \%$, and ethyl acetate extract by $50.77 \%$. The results of quantitative analysis using One Way ANOVA method showed that the water-ethanol, n-hexane, and ethyl acetate extracts significantly decreased the blood glucose levels of mice. The best antidiabetic activity was ethyl acetate extract with a decrease in rat blood glucose levels by 169 $\mathrm{mg} / \mathrm{kg} \mathrm{BW}$.
\end{abstract}

How to cite (APA $6^{\text {th }}$ Style):

Khaerati, K., Delina, A., Ihwan. (2020). Aktivitas Antidiabetes Ekstrak Air-Etanol, $n$-Heksan, dan Etil Asetat Uwi Banggai (Dioscorea alata L.) Dengan Metode Induksi Aloksan Pada Tikus Putih (Mus musculus). Jurnal Farmasi Galenika :Galenika Journal of Pharmacy (e-Journal), 6(2), 243-252. doi:10.22487/j24428744.2020.v6.i2.15154 


\section{ABSTRAK}

Hiperglikemia adalah keadaan meningkatnya kadar glukosa darah yang disebabkan tidak cukupnya enzim insulin yang diproduksi untuk mengontrol kadar gula darah dalam tubuh. Penelitian ini bertujuan untuk menentukan aktivitas ekstrak etanol-air, n-hexan dan etil asetat uwi banggai (Discorea alata L.) dalam menurunkan kadar glukosa darah pada mencil yang dimodelkan hiperglikemia yang diberikan induksi aloksan secara intraperitonial. 25 ekor tikus putih dikelompokan menjadi 5 kelompok hewan uji. Setiap kelompok terdiri dari 5 ekor mencit. Kelompok pertama dengan pemberian sediaan larutan Natrium Carboksi Metil Cellulosa 0,5\% sebagai plasebo, kelompok kedua menggunakan Glibenklamid 0,65 $\mathrm{mg} / \mathrm{kgBB}$ sebagai kelompok pembanding positif, kelompok ketiga suspensi ekstrak etanol-air, kelompok keempat ekstrak n-hexan, dan kelompok kelima ekstrak etil asetat dengan dosis $140 \mathrm{mg} / \mathrm{kgBB}$. Sediaan uji diberikan dalam waktu 14 hari pengujian secara oral. pengujian yang diukur adalah kadar glukosa darah mencit awal setelah diinduksi aloksan dan setelah pemberian suspensi sediaan uji . Hasil analisis kualitatif menggambarkan bahwa ekstrak air-etanol dapat menurunkan kadar glukosa darah hingga 31,39\%, ekstrak n-heksan sebesar 51,11\%, dan ekstrak etil asetat 50,77\% dan hasil analisis kuantitaif dengan motode One Way Anova satu arah diperoleh hasil ekstrak air-etanol, n-heksan dan etil asetat signifikan menurunkan kadar glukosa darah mencit. aktivitas antidiabetes yang paling baik adalah ekstrak etil asetat dengan penurunan kadar glukosa darah tikus sebesar $169 \mathrm{mg} / \mathrm{kg} \mathrm{BB}$.

Kata Kunci : Aloksan, Diabetes Melitus, Mus musculus, Ektrak, Dioscorea alata L.

\section{PENDAHULUAN}

Hiperglikemia adalah gangguan metabolisme dengan parameter peningkatan konsentrasi kadar gula di dalam darah yang disebabkan karena ketidakmampuan pankreas untuk memproduksi insulin dalam tubuh sehingga tidak dapat mengubah glukosa menjadi energi yang mengakibatkan penggunaan insulin yang diproduksi tidak efektifmengontrol konsentrasi glukosa di dalam darah (hiperglikemia) (Anonim, 2014).

Data Riskesdas 2013 menggambarkan bahwa diabetes melitus di Sulawesi Tengah dengan prevalensi sekitar 3,7\% (Anonim, 2013) dan International Diabetes Federation (IDF) 2015 menunjukan setelah mexiko, Rusia, Brasil, india Amerika Serikat dan Cina. Indonesia menempati ututan ke-7 dari 10 negara dengan jumlah penderita diabetes mellitus tertinggi. IDF juga memperkirakan pada tahun 2014 prevalensi penderita DM secara global berada pada 8,3\% dari total jumlah penduduk didunia akan menagalami peningkatan menjadi 387 juta kasus. Kecendrungan penambahan jumlah penduduk pada tahun 2020, maka prevalensi usia diatas 20 tahun akan diasumsikan dengan prevalensi 4,6\% (8,4 juta penderita). Kecenderungan peningkatan jumlah penderita dari tahun ke tahun semakin meningkat hingga diperkirakan tahun 2024 dengan jumlah penderita 10 juta jiwa (Suyono et al., 2007 dan Anonim, 2015).

Penangan terapi diabetes melitus ini umumnya merupakan penyakit jangka panjang dengan biaya mahal (Raja, 2008). Dalam pengobatan konvensional diabetes biasanya ditangani dengan beberapa cara yaitu dengan suntikan insulin atau obat oral. terapi insulin diperuntukkan untuk penanganan diabetes millitus tipe 1 dan tipe 2 dengan kondisi kadar gula darah yang parah. Tetapi sebagian besar penderita diabetes millitus tipe 2 diberikan terapi satu atau atau kombinasi obat oral. Beberapa kategori obat oral antidiabetes antara lain : golongan sulfonylurea, golongan biguanida, golongan tiazolidin (D’Adamo, 2008).

Studi literatur menggambarkan bahwa peningkatan jumlah penderita diabetes juga menyebabkan kebutuhan akan penggunaan obat antidiabetes juga meningkat. Sementara terapi penyakit diabetes dengan menggunakan obat sintetik menjadi masalah dikarenakan obat oral antihiperglikemik sintetis belum menjadi solusi dalam menangani penatalaksanaan terapi pada penderita dan terapi ini masih memiliki berbagai efek samping obat. sehingga dibutuhkan penanganan terapi alternatif dengan menggunakan obat tradisional menggunakan tanaman, hewan dan mineral dengan komponen bioaktif yang bersifat multikomponen untuk menurunkan kadar glukosa darah (Malviya et al., 2010). 
Bahan alam berupa obat tradisional dapat dimanfaatkan sebagai terapi diabetes millitus yang memliki potensi antidiabetes selain obat sintetik. (Hembing W., 2014). Uwi banggai (Dioscorea alata L.) merupakan salah satu sejenis umbi-umbian yang memiliki kandungan senyawa dengan kadar pati yang cukup baik digunakan sebagai sumber energi dalam penanganan dan pencegahan penyakit diabetes karena mengandung kadar gula yang sangat rendah (Yalindua A., 2014). Hasil penelitian yang diperoleh oleh Suresh Jagtap et al., (2013) mengamati bahwa ekstrak etanol dari uwi Dioscorea alata L. mengandung sejumlah besar flavonoid, flavonol, proanthocynidins dan senyawa fenolik. Flavonoid merupakan sumber senyawa yang digunakan sebagai suplemen antioksidan dengan mekanisme menghambat GLUT2, dan menghambat enzim fosfodiesterase serta menurunkan stress oksidatif pada tingkat sel penderita diabetes dengan demikian uwi banggai dimanfaatkan sebagai alternatif terapi diabetes yang memiliki efek hipoglikemi. (Ajie, R.b., 2015).

Uraian tersebut yang melatarbelakangi peneliti untuk untuk meneliti lebih lanjut efek antidiabetes Uwi Banggai dalam bentuk fraksi ekstrak etanol-air, n-Heksan, dan Etil Asetat. Perlakuan ini dilakukan untuk memisahkan golongan senyawa yang berpotensi sebagai antidiabetes millitus pada model hewan uji hiperglikemia yang diinduksi dengan menggunakan aloksan.

\section{METODE PENELITIAN}

\section{Alat dan Bahan}

Penelitian ini menggunakan alat antara lain; batang pengaduk, corong kaca, corong pisah, cawan porselen (Haldenwagner $\left.{ }^{\circledR}\right)$, disposible, gelas kimia, gelas piala, gelas ukur (IWAKI PIREX®), glucometer, hot plate, kandang mencit, labu takar (IWAKI PIREX®), mortar, neraca analitik (CTN®), oven (E-Scientific $®$ ), pipet tetes, rak tabung, sonde, stamper, tabung reaksi, vacum rotary evaporator (EYELA®N-1 200 B), waterbath, dan bahan yang digunakan adalah air suling, asam klorida, Etanol 96\%, Ekstrak etanol-air, n-hexan etil asetat Uwi Banggai (Dioscorea alara L.), Glibenklamid, Infus Natrium Clorida 0,9\%, dan suspensi Natrium Carboxil Metil Calisilat 0,5\%.

\section{Ekstraksi Sampel}

Serbuk Simplisia uwi Banggai varietas Paoateno dengan kadar air < 10\% ditimbang sejumlah $50 \mathrm{~g}$ dibungkus dengan kertas saring, dimasukkan ke dalam slongsong, kemudian diekstraksi menggunakan metode sokletasi dengan menggunakan $330 \mathrm{ml}$ pelarut etanol 96\%. Ekstraksi dilakukan secara kontinyu hingga pelarut kelihatan bening pada pipa kapiler alat soklet, ekstrak cair ditampung lalu diuapkan dengan rotary evaporator pada suhu $60^{\circ} \mathrm{C}$ hingga dihasilkan ekstrak kental uwi banggai.

\section{Pemisahan Golongan Senyawa}

Ekstrak kental uwi banggai yang diperoleh dipisahkan dengan ekstraksi partisi cair-ciar menggunakan tiga pelarut organik yaitu etanol-air, n-hexan dan etilasetat. Ekstraksi dilakukan sebanyak tiga kali ulangan dengan menggunakan $100 \mathrm{ml}$ pelarut (Firdaus et al., 2015). Setiap kali ekstraksi dengan menggunakan corong pisah. Pertama ekstrak kental dilarutkan dengan menggunakan air dan etanol 96\% dengan perbandingan $2: 1$, lalu dipisahkan dengan menggunakan $\mathrm{n}$-hexan $100 \mathrm{ml}$, campuran dikocok hingga homogen, kemudian didiamkan sampai terjadi pemisahan antara lapisan pelarut airetanol dan n-hexan, dipisahkan, lapisan n-hexan ditampung dalam wadah, lapisan air-etanol selanjutnya dimasukan kembali dalam corong pisah, lalu dilanjutkan pemisahan dengan menggunakan etil asetat. 


\section{Pembuatan Sediaan Uji Esktrak Uwi Ungu}

Ditimbang seksama masing-masing 84 mg ekstrak air-etanol, n-heksan, dan Etil Asetat Uwi Banggai, secara terpisah kemudian masing-masing disuspensikan dengan Natrium Carboxy Metil Cellulosa (Na-CMC) $0,5 \%$ dihomogenkan hingga terbentuk susupensi ekstrak uwi banggai, dicukupkan volumenya dalam labu takar hingga $10 \mathrm{~mL}$. Suspensi ini setara dengan dosis pemberian $140 \mathrm{mg} / \mathrm{kg}$ BB.

\section{Pembuatan Bahan Penginduksi (Aloksan)}

$110 \mathrm{mg}$ serbuk aloksan ditimbang dengan seksama, dimasukkan dalam labu takar $10 \mathrm{ml}$ ditambahkan infus $\mathrm{NaCl}$ 0,9\% dikocok hingga homogen dan dicukupkan volumenya hingga tanda.

\section{Pembuatan Na-CMC 0,5\%}

0,5 g Na-CMC ditimbang seksama dan $100 \mathrm{ml}$ air suling dipanaskan hingga suhu $70^{\circ} \mathrm{C}$, ditaburkan 0,5 g Na-CMC dalam $10 \mathrm{ml}$ air hangat didiamkan selama 10 menit hingga terbentuk mucilago selanjutnya digerus dan dicukupkan volumenya hingga $100 \mathrm{ml}$ kemudian di kocok hingga homogen.

\section{Pembuatan Obat Pembanding (Glibenklamid)}

Ditimbang glibenklamid sebanyak 15,6 mg, lalu disuspensikan dengan Na-CMC 0,5\% dalam labu takar, dikocok hingga homogen hingga terbentuk sediaan dalam bentuk susupensi.

\section{Perlakuan Terhadap Hewan Uji}

Penelitian ini menggunakan metode true eksperimental laboratorium menggunakan 25 ekor mencit sebagai model hewan uji, dibagi lima kelompok pengujian, setiap kelompok terdiri dari 5 ekor mencit. Seluruh hewan uji diukur kadar glukosa awal dengan menggunakan Nesco Multicheck Tester. Model hewan uji hiperglikemia dengan cara diinduksi dengan menggunakan aloksan $140 \mathrm{mg} / \mathrm{kg}$ BB secara intraperitonial setelah tiga hari pasca pemberian alkosan, kadar glukosa darah kembali diukur untuk memberikan efek diabetes militus pada mencit. (mencit DM jika pemeriksaan kadar glukosa darah $\geq$ $200 \mathrm{mg} / \mathrm{dL}$ ). Mecit yang diabetes diterapi dengan menggunakan ekstrak air-etanol, n-hexan, etil asetat dengan dosis masing $140 \mathrm{mg} / \mathrm{kg}$ BB dan pembanding positif glibenklamid 0,65 mg/kg Berat Badan, penentuan kadar glukosa akhir diukur pada hari ke-18. 


\section{HASIL DAN PEMBAHASAN}

\section{Identifikasi golongan senyawa uwi banggai}

Golongan senyawa Uwi Banggai Ungu yang potensial dikembangkan untuk memberikan efek farmakologi pada terapi diabetes millitus adalah alkaloid, flavanoid, steroid, tannin, dan saponin.

Tabel 1. Golongan senyawa Uwi Banggai Ungu berdasrkan kepolaran pelarut yang digunakan

\begin{tabular}{llcccc}
\hline \multirow{2}{*}{ No } & Golongan Senyawa & \multicolumn{3}{c}{ Ekstrak } \\
\cline { 3 - 6 } & $\begin{array}{l}\text { Etanol } \\
\mathbf{9 6 \%}\end{array}$ & $\begin{array}{l}\text { Air- } \\
\text { Etanol }\end{array}$ & Etil Asetat & $\begin{array}{c}\text { Etil } \\
\text { Asetat }\end{array}$ \\
\hline $\mathbf{1 .}$ & Flavonoid & + & - & + & - \\
\hline $\mathbf{2 .}$ & Saponin triterpenoid & + & - & - & + \\
\hline 3. & Tanin & + & - & - & - \\
\hline $\mathbf{4 .}$ & Steroid & + & - & - & - \\
\hline $\mathbf{5 .}$ & Alkaloid & + & - & - & - \\
\hline $\mathbf{6 .}$ & Terpenoid & + & + & - & - \\
\hline
\end{tabular}

Keterangan $:(+)=$ Ada,$(-)=$ Tidak Ada

Tabel 2. Selisih Pengukuran Kadar Glukosa Darah Mus musculus setelah terapi uwi banggai

\begin{tabular}{cccc}
\hline \multirow{2}{*}{ Kelompok Perlakuan } & \multicolumn{2}{c}{$\begin{array}{c}\text { Selisih Penurunan Rerata Kadar Gula } \\
\text { Darah mg/dL }\end{array}$} & $\begin{array}{c}\text { \% Penurunan } \\
\text { Kadar Gula } \\
\text { Darah }\end{array}$ \\
\cline { 2 - 3 } & $\Delta_{1}$ & $\Delta_{2}$ & $1,01 \%$ \\
\hline Kontrol (-) & 5 & 3 & $43,09 \%$ \\
\hline Kontrol (+) & 95 & 128 & $51,11 \%$ \\
\hline Fraksi n-Heksan & 95 & 156,4 & $50,77 \%$ \\
\hline Fraksi Etil Asetat & 82,2 & 158 & $31,39 \%$ \\
\hline Fraksi Air & 65,6 & 89,6 & \\
\hline
\end{tabular}

Tabel 2. Profil rerata Kadar Gula Darah Mencit

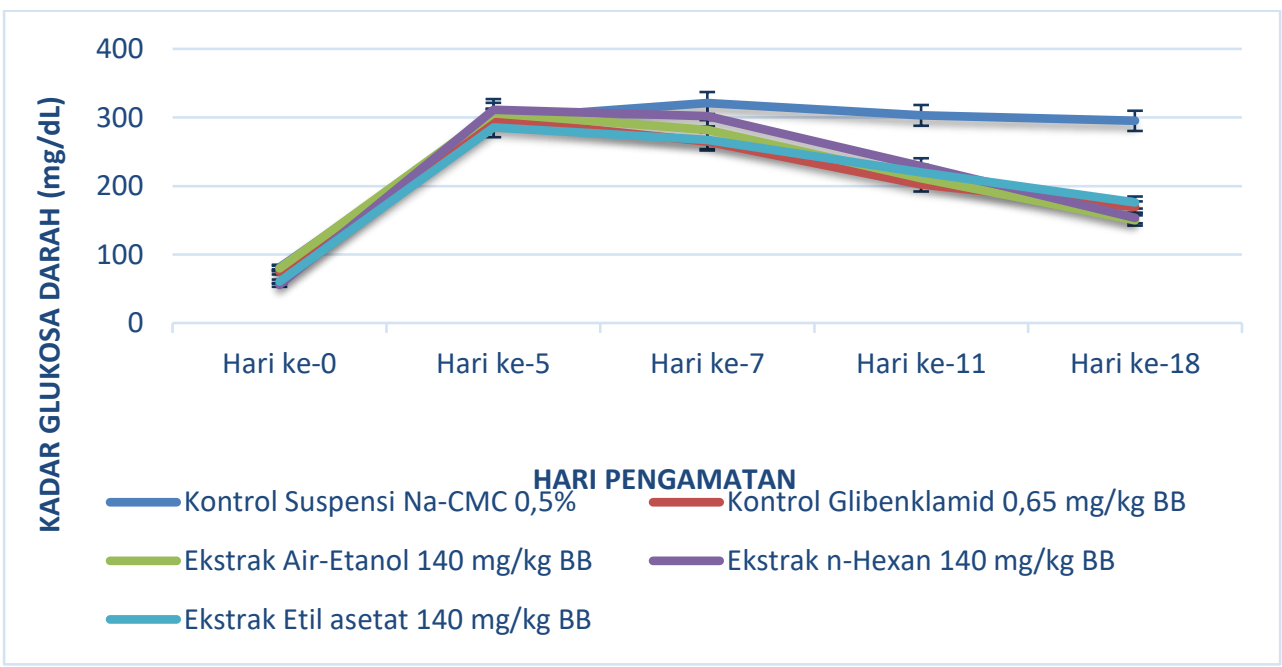

Penelitian ini menggunakan ekstrak Uwi Banggai varietas paoateno yang telah diidentifikasi di Unit Pelaksana Tugas Herbarium Sumber Daya Hayati Sulawesi Tengah Universitas Tadulako untuk memastikan bahwa sampel yang diteliti adalah Uwi Banggai varietas paoateno. Uwi Banggai varietas 
paoateno diproses untuk dijadikan ekstrak kental melalui proses soxhletasi. Proses ini digunakan karena simplisia uwi banggai dalam bentuk serbuk lunak sehingga mudah untuk proses ekstraksi selain hal tersebut metode ini menghasilkan jumlah ekstrak lebih banyak dengan penggunaan pelarut lebih sedikit dibanding metode ekstraksi lain dan model ekstraksi yang dilakukan secara kontinyu (Heinrich, 2004). Penggunaan etanol $96 \%$ sebagai Cairan penyari karena simplisia yang digunakan telah dikeringkan sehingga sedikit menyerap air dari udara, pelarut lebih selektif dalam menarik komponen senyawa kimia baik polar maupun nonpolar dikarenakan etanol pelarut organik yang memiliki kemampuan untuk mengikat air pada berbagai perbandingan. Cairan penyari Etanol 96\% juga bersifat nontoksik, (Marjoni, 2016). Hasil penyarian diuapkan dengan rotary evaporator hingga diperoleh ekstrak kental dengan jumlah 203,36 gram dan rendamen ekstrak yang diperoleh yaitu 2,49\%.

Ekstrak etanol Uwi Banggai Ungu diidentifikasi secara kualitatif menggunkan metode pereaksi kimia dengan tujuan memastikan golongan senyawa bioaktif yang terdapat dalam ekstrak. Hasil uji identifikasi secara kimia terhadap ekstrak yang diperoleh menunjukkan bahwa Uwi Banggai Ungu mengandung senyawa flavonoid, alkaloid, saponin, tanin dan steroid. Kemudian dilakukan pemisahan golongan senyawa bioaktif berdasarkan kepolaran pelarut yang digunakan pada ekstrak uwi Banggai ungu menunjukkan bahwa ekstrak uwi Banggai ungu memberikan hasil positif adanya terpenoid pada ekstrak n-Heksan, Flavonoid pada ekstrak etil asetat dan pada air-etanol senyawa yang terkandung yaitu glikosida triterpenoid. Hasil golongan senyawa ini sejalan dengan penelitian Primadia \& Ayudina tahun 2018.

Pemisahan golongan senyawa pada ekstrak uwi bangga dilakukan secara partisi cair-cair, pemisahan ini dilakukan untuk mendapatkan golongan senyawa berdasarkan tingkat kepolaran pelarut dan jenis senyawa bioaktif yang mempunyai potensi antidiabetes yang kemudian diujikan secara invitro pada mencit. Proses pemisahan senyawa dilaksanakan secara bertahap dengan menggunakan cairan penyari $\mathrm{n}$-hexan dan etil asetat yang tidak saling tercampurkan dengan menggunakan jumlah pelarut secara berulang untuk meperoleh hasil pemisahan yang sempurna. Hasil pemisahan dengan menggunakan nhexan yang dispesifikkan untuk menyari golongan senyawa terpenoid positif uwi banggai mengadung senayawa terpenoid yang merupakan senyawa dengan potensi sebagai antidiabetes (Sukandar, D, S. Hermanto, 2009), kemudian dilanjutkan dengan dengan menggunakan Etil Asetat yang bersifar semipolar yang diperuntukkan untuk memisahkan senayawa flavonoid, dan Air digunakan sebagai pelarut polar untuk memisahkan senyawa glikosida terpenoid (Harbourne 1984).

Uji aktivitas antidiabetes millitus menggunakan Mus musculus jantan yang umumnya telah banyak digunakan pada penelitian laboratorium. Mus musculus memiliki jumlah anak yang banyak setiap kelahiran, siklus hidupnya yang relatif pendek, dan penanganannya yang lebih mudah, dapat digunakan sebagai model hiperglikemia pada usia 2-4 bulan dan memiliki keadaan fisiologi menyerupai tubuh manusia. Menurut Cheta (1998), hewan sebagai model diabetes millitus harus diindukasi melalui pangkreaktomi, menggunakan ageng senayawa kimia sebagai diabetogenik, dan menggunakan virus; serta model diabetes secara spontan menggunakan mencit denga model non-obese diabetic (NOD), pemodelan ini dapat digunakan untuk mengetahui kondisi peningkatan kadar glukosa darah dengan sifat dan karakteristik yang mirip dengan kondisi diabetes mellitus pada manusia (Nugroho, A.E., 2006).

Penelitian ini dilakukan dengan menggunakan 5 kelompok uji, yaitu Suspensi Na-CMC 0,5\% sebagai kontrol negative sebagai pembawa sediaan uji dan juga tidak memiliki efek antihiperglikemia pada pengujian. Glibenklamid dengan konsentrasi $0,65 \mathrm{mg} / \mathrm{kg}$ berat badan sebagai kontrol positif. Glibenklamid adalah obat lini pertama yang digunakan sebagai terapi diabetes milllitus karena dapat merangsang insulin dalam sel $\beta$-pangreas (Mahendra, Krisnatuti, Tobing, dan Boy, 2008). Adanya interaksi molekul Adenosin tripospat (ATP) yang tersensitivitasi kanal kalsium membran sel $\beta$ sehingga menyebabkan terjadinya dopolarisasi membran, hal ini menyebabkan terbukanya kalsium kanal dan menyebabkan $\mathrm{Ca}^{2+}$ akan masuk ke sel $\beta$-pangreas dan menyebabkan perangsangan granula yang mengakibatkan insulin keluar dari $\beta$-pangreas (Suherman, 2007). dan ekstrak air-etanol, n-hexan 
dan etil asetat $140 \mathrm{mg} / \mathrm{kg}$ BB sebagai kelompok sediaan uji yang efektif berpotensi untuk mengurangi kadar glukosa darah pada pada mencit hngga ke kadar glukosa darah normal.

Aklimatisasi Mus musculus dilakukan selama 7 hari untuk menyesuaikan kondisi dengan lingkungan baru untuk memastikan hewan uji dalam keadaan sehat sehingga nantinya tidak mempengaruhi kondisi penelitian dalam menurunkan kadar glukosa darah. Hewan uji dipuasakan selama 16 jam dan diukur kadar glukosa darah awal, hal ini dilakukan untuk memastikan kadar glukosa normal setiap hewan uji. Kadar glukosa diperoleh antara 55,6 $\pm 11,523-81 \pm 12,0 \mathrm{mg} / \mathrm{dL}$, kisaran ini sesuai dengan kadar glukosa normal pada mencit yaitu $62-175 \mathrm{mg} / \mathrm{dL}$ (Malole dan Pramono, 1989). Induksi aloksan 65 $\mathrm{mg} / \mathrm{kg}$ Berat Badan dinjeksikan melalui intraperitonial untuk menaikkan glukosa darah mencit hingga diperoleh hewan uji yang hiperglikemia (Szkuldelski, 2001). Mekanisme ini terjadi memalui sel $\beta$ pangkreas karena aloksan memiliki gugus sulfahidril yang akan mengalami reaksi oksidasi glutatsi peptida menghasilkan asam dialurat dan selanjutnya mengalami reoksidasi dismutasi dengan produk radikal bebas superoksida, selanjutnya menghasilkan Hidrogen proksida $\left(\mathrm{H}_{2} \mathrm{O}_{2}\right)$ dengan jalur reaksi dismutase, adanya $\mathrm{Fe}^{2+}$ dan $\mathrm{H}_{2} \mathrm{O}_{2}$ akan membentuk radikal hidroksil. Radikal hidroksil ini bersifat sangat reaktif melalui mekanisme reaksi fenton sehingga merusak Deoksiribosa Nukleat Acid sel beta pankreas. Selain mekanisme ini alkosan juga dapat mengganggu sistem keseimbangan ion kalsium intraseluler, dengan dua mekanisme ini aloksan mengakibatkan kerusakan jumlah dan massa sel pangkreas yang menyebabkan sekresi insulin berkurang dan menurunnya sensitivitas reseptor insulin dalam sel pangreas, hati, otot dan sel adiposa (Lenzen \& Panten, 1988). setelah 5 kali 24 jam penginduksian aloksan hewan uji mengalami kenaikan kadar glukosa darah antara 285,4 $\pm 52,400$ $311,2 \pm 87,138 \mathrm{mg} / \mathrm{dL}$ data ini menggambarkan bahwa seluruh mencit dikategorikan hiperlipidemia, Setelah mencit mengalami hiperglikemia, kemudian dilanjutkan dengan pemberian perlakuan selama 14 hari secara oral.

Glukosa darah hewan uji setelah pemberian suspensi glibenklamid dan ekstrak uwi banggai air-etanol, $\mathrm{n}$-hexan etil asetat dosis $140 \mathrm{mg} / \mathrm{kg}$ Berat Badan mengalami Penurunan pada hari ke-11 hingga hari ke18 perlakuan sedangkan kontrol negatif tetap hiperglikemia. Kelompok kontrol glibenklamid dapat menurunkan kadar glukosa darah dengan persentase efek penurunan kadar glukosa darah 43,09\%, untuk ekstrak n-heksan sebesar 51,11\%, ekstrak etil asetat 50,77\%, ekstrak air-etanol 31,39\%, dan kelompok kontrol Na-CMC 0,5\% sebesar 1,01\%, dengan kisaran penurunan kadar glukosa darah antara 149,6 \pm $31,855 \mathrm{mg} / \mathrm{dL}-295 \pm 58,125 \mathrm{mg} / \mathrm{dL}$. Analisis ANOVA satu arah pada taraf signifikansi $95 \%$ menunjukkan bahwa nilai probabilitas berada pada $\mathrm{P}<0,01$ hal ini menggambarkan bahwa terdapat perbedaan efek antar kelompok dalam menurunkan glukosa darah mencit pada setiap perlakuan. Potensi kemampuan ekstrak air-etanol, n-hexan dan etil asetat dosis $140 \mathrm{mg} / \mathrm{kg}$ BB dalam menurunkan glukosa darah sebanding dengan kontrol positif glibenklamid. Salah satu golongan sulfonylurea adalah glibenklamid yang digolongkan dalam antidiabetik oral dengan mekanisme kerjanya menstimulasi sel beta pankreas untuk melepaskan sekresi insulin (Novrial et al, 2012). Sedangkan senyawa yang terdapat dalam ekstrak uwi banggai yang diidentifikasi secara kimia adalah senyawa flavonoid yang didispersikan dalam suspensi Na-CMC 0,5\% dalam sedian uji memiliki potensi dalam menurunkan glukosa darah mencit, hal ini sesuai studi eksperimen menunjukkan bahwa senyawa biaktif flavonoid yang terdapat dalam tanaman terbukti dapat menurunkan kadar glukosa darah pada hewan uji yang mengalami hiperglikemia dengan mekanisme mengatur aktivitas enzim dalam proses metabolisme karbohidrat dalam tubuh (Brachmachari, 2011) dan senyawa flavonoid ini merupakan senyawa fenolik alam yang memiliki kemampuan bioaktif antioksidan yang dapat digunakan dalam proses netralisir senyawa yang bersifat radikal bebas dalam proses kerusakan sel $\beta$-pangkreas dan juga senyawa ini dapat memperkuat sekresi insulin tersentisasi melalui pengaktifan kaskade sinyal cAMP. Flavonoid memiliki kemampuan dalam menghambat dan pengkhelat logam pada reaksi Fenton dan Haber-Weiss yang penting sebagai sumber radikal oksigen reaktif (Shahidi \& Wanasundara, 1992). Flavonoid diketahui mampu menangkap radikal bebas (ROS/Reactive Oxygen Species atau RNS/Reactive Nitrogen Species) melalui transfer electron, serta menghambat reaksi peroksidasi (Lugasi, Hovari, Sagi, dan Biro, 2003). Flavonoid dapat memproteksi sel-sel makrofag dari stress oksidatif melalui mekanisme menghambat aktivitas enzim dari derivat glutathione, yaitu glutathione s-transferase (GST) (Moskaug, Carlsen, 
Myhrstad, \& Blomhoff, 2005). Senyawa flavonoid menunjukkan mekanisme kerja sebagai antidiabetes dengan meningkatkan fungsi dari sel $\beta$ - pankreas dan membantu merangsang sekresi insulin (Luvacinova, et.al., 2008; Dheer \& Batnagar, 2010).

Ekstak n-heksan uwi banggai teridentifikasi mengandung senyawa terpenoid. Senyawa ini dapat meningkatkan penyerapan glukosa dengan bertindak meniru kerja insulin dan sebagai insulin sensitizer (Lee \& Thuong, 2010). Juga membuktikan bahwa senyawa terpenoid mempunyai kemampuan untuk menstimulasi sel-sel $\beta$-pangkreas untuk memperproduksi insulin (Jaiswal et al., 2009). Tanaman ini juga mengandung senyawa Alkaloid yang mempunyai kemampuan dalam regenerasi sel beta pankreas yang mengalami rusak (Arjadi, F dan P. Susatyo, 2010). Kandungan alkaloid berupa glikosida dapat menurunkan kadar gula darah dan dapat meningkatkan toleransi glukosa pada diabetes tipe 2 (Cheng, 2008).

\section{KESIMPULAN}

Ekstrak air-etanol dapat menurunkan kadar glukosa darah hingga 31,39\%, ekstrak n-heksan sebesar $51,11 \%$, dan ekstrak etil asetat 50,77\% dan ketiga ekstrak signifikan menurunkan kadar glukosa darah mencit. aktivitas antidiabetes yang paling baik adalah ekstrak etil asetat dengan penurunan kadar glukosa darah tikus sebesar $169 \mathrm{mg} / \mathrm{kg} \mathrm{BB}$.

\section{DAFTAR PUSTAKA}

Ajie, R. B. (2015). White Dragon Fruit (Hylocereus undatus) Potential As Diabetes Mellitus Treatment. Faculty of Medicine. Lampung University.

Anonim, (2005), Pharmaceutical Care Untuk Diabetes, Direktorat Bina Farmasi Komunitas Dan Klinik Ditjen Bina Kefarmasian Dan Alat Kesehatan Departemen Kesehatan, Jakarta.

Aprianita, A. (2010). Assessment of underutilized starchy roots and tubers for their applications in the food industry, A thesis submitted in fulfillment of the requirements of the degree of Master of Science. School of Biomedical and Health Science, Victoria University, Australia.

Arjadi, F dan P. Susatyo. (2010). Regenerasi Sel Pulau Langerhans Pada Tikus Putih (Rattus norvegicus) Diabetes Yang Diberi Rebusan Daging Mahkota Dewa (Phaleria macrocarp (Scheff.) Boerl.). Vol. 2, No. 2 Juli-Desember 2010

Badan Penelitian dan Pengembangan Kesehatan. (2013). Riset Kesehatan Dasar (RISKESDAS) 2013. Laporan Nasional 2013, 1-384. https://doi.org/1 Desember 2013.

Bakova Z., Kolesarova A. (2012). Bioflavonoid Absorbtion and Effect on Animal Cells. J Microbiol. Biotech \& Food Sci: 2 (2): 426-33.

Cheng, H. (2008). A cell-based screening identifies compounds from the stem of Momordica charantica that overcome insulin resistance and activate AMP-activated protein kinase. J Agric Food Chem, 56(16).

Harborne, J.B. (1984). Metode Fitokimia Penuntun Cara Modern Menganalisa Tumbuhan. Penerjemah: KOsasih Padmawinata dan Iwang Soediro. Terbitan Kedua, ITB, Bandung.

Yalindua, A (2014) Potensi Genetik Klon Tanaman Uwi (Dioscorea alata L.) Asal Banggai Kepulauan Sebagai Sumber Pangan Dalam Menunjang Ketahanan Pangan Nasional. Disertasi. Institut Pertanian Bogor. Bogor.

Ruslan, (2013) Inventarisasi dan Identifikasi Sumber Daya Genetik Tanaman Umbi-Umbian Di Kabupaten Banggai Kepulauan, Balai Pengkajian Teknologi Pertanian, Palu-Sulawesi Tengah 
Tambayong. (2001). Anatomi dan Fisiologi Untuk Keperawatan. Cetakan I. EGC. Jakarta.

Gunawan, S. G., Setiabudy, Nafrialdi, \& Elysabeth. (2007). Farmakologi dan Terapi. Jakarta: Departemen Farmakologi dan Terapeutik Fakultas Kedokteran Universitas Indonesia.

Jaiswal, D., Rai, P.K., Kumar, A., Mehta, S., \& Watal, G. (2009). Effect of Moringa oleifera lam leaves aqueous extract therapy on hyperglucemic rats. Journal of Ethnopharmacology, 123(3), 392-396.

Katzung, B. G. (2012). Farmakologi Dasar dan Klinik (8 ed.). Jakarta: Salemba Medika.

Lenzen, S., \& Panten, U. (2008). Alloxan: History and Mechanism of Action. Diabetologia, 31, 337342.

Novrial, D; Sulistyo, H; dan Setiawati. (2012). Comparison of Antidiabetic Effect of Honey, Glibenclamide Metformin And Their Combination In The Streptozotocin Induced Diabetic Rat. Prosiding Seminar Nasional Kesehatan. Kesehatan Masyarakat FKIK Unsoed. Vol2(3).

Nugroho, Agung Endro. (2006). Review Hewan Percobaan Diabetes Mellitus : PAtologi dan Mekanisme Aksi Diabetogenik. UNS. Surakarta.

Primadia, A, R., (2018). Uji Parameter Spesifik Ekstrak Etanol Ubi Banggai ungu (Dioscorea alata L.) asal Kabupaten Banggai Sulteng, FMIPA, Universitas Tadulako, Palu.

Pearce, E, C. (2012). Anatomi dan Fisiologi Untuk Paramedis. Jakarta: PT. Gramedia Pustaka Utama.

Sulistyowati, Ningsih. (2004). Kelenjar Pankreas, Makalah. Prodi Psikologi Fak. Dakwah IAIN Sunan Ampel. Surabaya.

Szkudelski. (2001). The Mechanism of Alloxan and Streptozotocin Action in B Cells of the Rat Pancreas. Poland: Departement of Animal Physiologi and Biochemistry, University of Agriculture.

Widowati, W. (2008). Potensi Antioksidan Sebagai Antidiabetes. JKM, 7(2), 1-9.

Malviya, N., Jain, S., \& Malviya, S. (2010). Review Antidiabetic Potential of Medicinal Plants. Acta Poloniae Pharmaceutica-Drug Research, 67(2), 113-118.

Rohilla, A. \& Ali, S., (2012). Alloxan Induced Diabetes: Mechanism and Effects, International Journal of Research in Pharmaceutical and Biomedical Sciences, 3(2): 819-823.

Xing, R., He, X., Liu, S., Yu, H., Yukun, Q., Chen, X., Li, K., Li, R., and Pancheng Li, (2015), Antidiabetic Activity of Differently Regioselective Chitosan Sulfates in Alloxan-Induced Diabetic Rats, Marine Drugs.

Sukrasno dan Tim Lentera, (2003), MIMBA Tanaman Obat Multi Fungsi, PT. Agro Media Pustaka, Jakarta.

International Diabetes Federation, (2015), Diabetes Atlas Seventh Edition, http://www.idf.org/aboutdiabetes/facts-figures, Diakses 14 Februari 2018.

Jusman, S.W., Halim, A (2009) Oksidative Stress in Liver Tissue of Rat Inducet by Cronic Systemic Hypoksia. Makalah Kesehatan, 13 (1,34-38).

World Health Organization Europe. (2013). Diabetes: The Challenge of Diabetes. Tersedia dari: URL: HYPERLINK www.euro.who.int

Clare-salzler MJ, Crawford JM, Kumar V. (2007). Pankreas. Dalam: Hartanto H, Darmaniah N, 
Wulandari N, editor (penyunting). Buku Ajar Patologi Robbins (hlm. 723-4). Edisi ke-7. EGC. Jakarta.

Suyono, Slamet. (2007). Penatalaksanaan Diabetes Melitus Terpadu. Fakultas Kedokteran. Universitas Indonesia. Jakarta. Hal: 8-40.

D’Adamo., P.J., and Whitney C. (2008). Diabetes - Penemuan Baru Memerangi Diabetes Melalui Diet Golongan Darah (Terjemahan dari DIABETES: Fight It With The Blood Type Diet). Penerbit BFirst. Yogyakarta. Hal:32-33.

Raja, L., L. (2008). Uji Efek Ekstrak Etanol Biji Mahoni (Swietenia mahagoni Jacq) Terhadap Penurunan Kadar Glukosa Darah Tikus Putih, Fakultas Farmasi. Universitas Sumatera Utara. Medan.

Wells, Barbarag., Dipiro, Josepht., Schwinghammerterry L., Dan Dipiro, Cecily V. (2009). Pharmacotherapy Handbook Seventh Edition. Mcgraw-Hill Medical. New York. Hal: 210. 